\title{
A Literature-Based Reading Instructional Model for Islam-Affiliated University in Indonesia
}

\section{Dedi Irwansyah}

Dr., English Department, State Islamic Institute of Metro, Indonesia, dedi.irwansyah@student.uny.ac.id

\section{Burhan Nurgiyantoro}

Prof., Faculty of Language and Arts, Yogyakarta State University, Indonesia, burhan@uny.ac.id

\section{Sugirin}

Prof., English Language Education, Yogyakarta State University, Indonesia, sugirin@uny.ac.id

The use of literary texts from various sources to teach reading at Indonesian Islam-affiliated university was still under research. This study offered a contextually-relevant and culturally-sensitive reading instructional model for such particular university which sought to blend western, Indonesian, and Islamic cultures in harmony. The model was developed through studying relevant literature and research findings, designing a model, field testing the model, and revising the model. This research involved the feedback and suggestion for improvement from three experts, five practitioners, and thirty-three students so as to emphasize the local voice in developing the reading instructional model. The findings revealed that the developed model should include such components as philosophy, input, process, and output with an adequate elaboration of each. In implementing the developed model, teachers should utilize literary text from western, Indonesian, and Islamic traditions. They should also emphasize the Indonesian culture and Islamic tradition aspects without losing their sight the international orientation of the English language teaching.

Keywords: literature-based instruction, reading instruction, instructional model, Islamaffiliated university, multiculturalism

\section{INTRODUCTION}

The discussion of chaos theory in a foreign language teaching has led to the phenomenon of butterfly effect suggesting the complexity of elements that influence the teaching and learning process. An apparently insignificant factor might turn out to be

Citation: Irwansyah, D., Nurgiyantoro, B., \& Sugirin. (2019). A Literature-Based Reading Instructional Model for Islam-Affiliated University in Indonesia. International Journal of Instruction, 12(3), 577-594. https://doi.org/10.29333/iji.2019.12335a 
significant after a detailed exploration within the spirit of inclusiveness and interface (Brown, 2007). The authors argue that the use literary texts to teach English in Islamaffiliated university in Indonesia reflects the butterfly effect. When reconceptualised as an instructional model, literary text can serve as a springboard to explore the complex factors of teaching English at the Islam-affiliated university. Teaching of English as a foreign language (TEFL) at an Islam-affiliated university in Indonesia is intriguing particularly when it deals with whose or what cultures to be included. English cultures and values, on one hand, should be exposed as they are embedded within the English language. Indonesian cultures and values, on the other hand, should also be introduced to strengthen students' national pride. Furthermore, Islamic cultures and values should also be incorporated so as to emphasize the particularity of the university. This article supports the notion stating that an instructional innovation in TEFL should consider students' communal and regional cultures ((Budsaba \& Todsapon, 2018). Cultures are best introduced through a literature-based instruction as literature is often taken as a culture in action.

Literary texts have been widely believed to be motivating materials that foster whole person education (Lazar, 2009) including cultural awareness, language skills, personal growth (Carter \& Long, 1991) and religion understanding (Bayat \& Jamnia, 1994). Besides, developing a literature-based reading instructional model at an Islam-affiliated university in Indonesia leads to an interface among the Western, Indonesian, and Islam cultures and tradition.

Lazar (2009) urges that in the last decade more and more English language teaching practitioners show strong interest in how literary texts might be effectively and interestingly utilized to teach a foreign language. Lazar's statement seems to be true when Collie and Slater (1994) point out some positive reasons for using literature in a language classroom. Accordingly, a literary text serves as valuable authentic material, fosters cultural enrichment, helps language enrichment, and encourages personal involvement. The text offers themes which are closely related to fundamental human issues. It provides foreign learners with insight into cultural background of the target language. As it encourages students' personal involvement, the lexical, syntactical, and cultural content, a literary text becomes more memorable. A well-chosen literary text might also serve as an excellent prompt for oral activities.

Alwasilah (2014) maintains that the use of literature in education will provide the students with cross-cultural understandings and universal values which in turn will make them more human. Maley (2012) argues that literary texts provide the students with phonological, lexical, syntactic, and discoursal inputs which are essential to effective language learning. They also serve as suitable resources to develop students' language awareness of language variation, social appropriacy, and ideological bias. Thus, the literary text is an ideal resource that an English teacher could use to help students develop their linguistic knowledge, language skills, affective domain, cultural awareness, and spiritual dimension.

A growing body of the study shows a sense of crisis as well as the importance of using literature from various traditions to teach English at an Islam-affiliated university. Khairuddin, et al., (2014) urge that learning materials from West often represent secular 
perspective that needs to be encountered. Madya (2015) emphasizes that literature helps students develop their English communicative competence, imagination, creativity, and spiritual intelligence. Dewi (2016) maintains that reading literary texts from different traditions will reduce prejudice and intolerance. Hadi (2016) states that the genre of Islamic literature has not been adequately explored by the stakeholders of the Islamaffiliated university in Indonesia. Muslim (2017) maintains that the integration of the students' national heritage narratives into the English learning materials improves students' English skills and sense of national pride. Those studies imply the need for incorporating literary texts from western, Indonesian, and Islamic tradition in the development of a literature-based reading instructional model for an Islam-affiliated university in Indonesia. Such incorporation brings about novelty as a central issue to TEFL in the 21st century (Motallebzadeh, et.al., 2018). The novelty of this research lies in the use of literary texts form Islamic tradition, together with the texts from western and Indonesian traditions, in teaching English. Specifically, the purpose of this research is to generate and validate a reading instructional model, which includes literary texts from various relevant traditions, for students of English department in Islam-affiliated universities in Indonesia.

\section{LITERATURE REVIEW}

\section{Literature-Based Reading Program}

Literature-based reading instruction refers to the use of literature as the basis for classroom activities and tasks. One of the prominent advantages of the use of literature in a language classroom is that it helps students construct meaning interestingly (Mohammad, et al., 2012). It is characterized by some strategies: students are offered to personally select the literary texts to read; a group of students is conditioned to read and respond to the same literary text; and students are assigned to read different texts with similar themes and then discuss the insights within the texts (Vacca, et al., 2006). It is based on the reader response perspective which believes that the interpretation of a text is influenced by such factors as a particular reader, text, context, and certain moment. Rosenblatt (2005, p.30) asserts that 'the finding of meanings involves both the author's text and what the reader brings to it'. Reading is seen as meaning-making process manifested in the interaction between the author's text and the reader's prior knowledge and experience.

A literature-based reading instruction involves efferent reading and aesthetic reading. The former focuses on the information in the text while the latter deals with the association, feelings, attitudes, and ideas derived from the text (Cox, 2012). The literature-based reading instruction should encourage the involvement of both types of reading. Consequently, the reading of literary texts should focus on the information within the text and students' psychological responses toward the information (Richards, 2015). Literature-based reading instruction should be designed in line with the students' knowledge of linguistic features and personal context (Lazar, 2009).

\section{Instructional Model}

The term 'model' has been used variously. Joyce, et al., (2009, p.24), for example, propose the term 'models of teaching' ranging from the information-processing models 
to the behavioral models. Meanwhile, Carterand Long (1991) introduce such terms as the cultural model, the language model, and the personal model in teaching literature. As for this research study, the term model is based on Stern's (1991) definition of a teaching-learning model. Accordingly, teaching-learning consists of four main components namely context, presage, process, and product. The context refers to the environment, schools, community, and condition where the teaching-learning takes place. The presage is pertinent to the variables that foreshadow the future instructional process such as the characteristics of students and teachers. The process deals with what the teacher and students do in the classroom while product refers to the outcome of the teaching-learning process. The interconnection between the four main components is visualized through a diagram as presented in Figure 1.

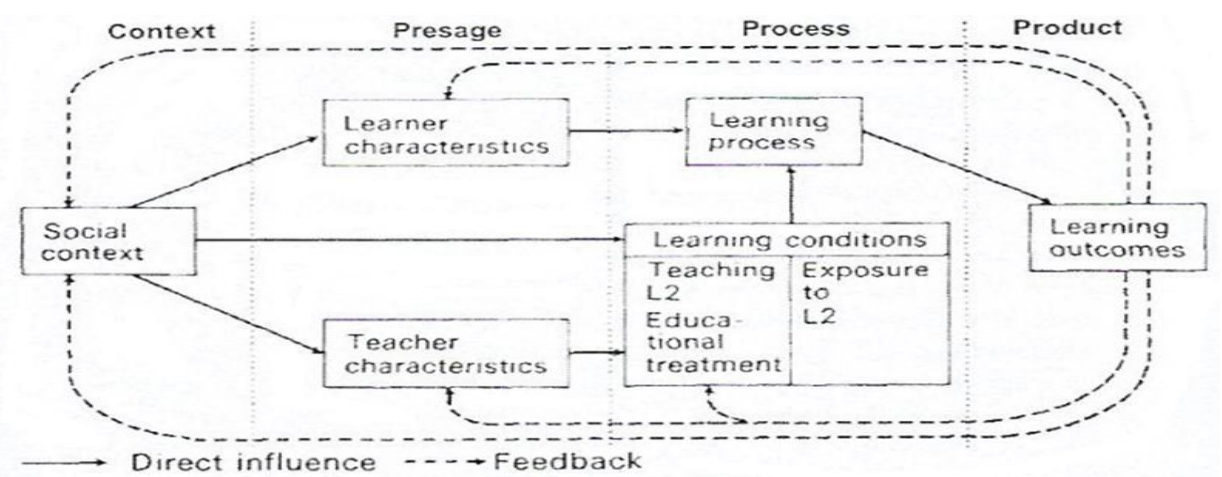

Figure 1

Stern's Teaching-Learning Model

A teaching-learning model, thus, refers to a visualized framework representing the interconnectedness of its supporting components. In order for the framework to be applicable, instructional kits like syllabus and coursebooks are needed. The term 'teaching-learning' itself, however, might be a general concept. To connect the term with a particular educational environment or social system, one might use the term of instruction (Alwasilah, 2010). In this research study, the term 'instructional model' is used to denote the 'teaching-learning model'.

\section{Grounds of Instructional Model Development}

\section{Post-method Pedagogy}

Post method pedagogy is a critical response toward pre-method era and method era emphasizing that the existing teaching methods are apparently different in the lower procedures and tend to reach similar points in the higher ones. While the differences among the existing methods are not that significant, a rigid implementation of a certain method is against the notion of teaching is an art which requires intuitive sense (Madya, 2013). Moreover, a teaching method is not free from any political interests upon which an English teacher should be aware of. Post method pedagogy helps language teachers reflect their own teaching method and find teaching principles that linguistically, culturally, and politically best fit their own teaching contexts. 
Post method pedagogy accommodates the global and local needs of English language teaching. The global needs are underpinned by the five global perspectives: post national, postmodern, postcolonial, post-transmission, and post method. The post national perspective suggests that an English teacher not to ignore the fact that all nations in the world are interconnected in which the transfer of ideas, values, and cultures might occur rapidly. The postmodern perspective reminds the teacher that his or her different teaching situation should be taken into account in order to enrich the narration of English language teaching. The postcolonial perspective suggests the teacher that ELT as a foreign language might be a new colonialism in scholastic, cultural, linguistic, and economic domains. ELT might be a powerful instrument for English speaking countries to propagate western knowledge and western culture that endanger students' use of their local language and culture. ELT is a worldwide industry which is economically beneficial for the inner circle countries. The post-transmission perspective encourages the teacher to reflect and contextualize an externally produced knowledge. He or she must not be a passive transmitter of language pedagogy initiated by western experts (Kumaravadivelu, 2012a). The post method perspective demands that an English teacher make a change by observing, reflecting, analyzing, evaluating, and monitoring his or her own teaching approach.

Further, the local needs of English language teaching are accentuated through three operating principles: particularity, practicality, and possibility. These principles serve as anchor and means to integrate teacher's beliefs, values, and expectations into measurable educational outcomes. The principle of particularity emphasizes that an English teacher should reflect and accommodate students' local, institutional, social, and cultural contexts. The teacher should assess the contexts and integrate them into the instructional activities. The principle of practicality reminds that an English teacher should bridge the theories and practices by creating practical and local relevance of ELT for the students (Madya, 2013). The principle of possibility reminds English teacher that ELT should be projected onto student's individual identity formation (Kumaravadivelu, 2012a). In line with the principle of particularity, it is worth noting that EFL teachers' commitment to their institutional needs is part of their professional ethics (Kafi, et.al, 2018). Educators at Islam-affiliated university are called for integrating prophetic tradition and Qur'anic verses, as the primary sources of Islamic pedagogy, into the learning materials (Purwati, et.al., 2018; Alkouatli, 2018).

Post method pedagogy deserves English teachers' attention in outer circle countries, let alone English teachers in such particular contexts as Islam-affiliated universities in Indonesia. The teachers should be sensitive to Indonesia local culture, Islamic tradition, identity formation, and colonial representative. They should continuously reflect and theorize their own teaching practices without ignoring the global goal of ELT, which is to interact with the international community.

\section{English as an International Language}

The rapid changes in the field of instructional approaches are not only caused by the notion of post method era but also by the concept of English as an international language (EIL). By introducing the concepts of inner circle, outer circle, and expanding 
circle, EIL has brought about changes into the sociolinguistic landscape of English. The inner circle refers to countries where English is the native or first language; the outer circle includes such countries where English is not the native language but does play an institutional or historical role; and the expanding circle refers to countries where English is the most popular foreign language (Matsuda, 2012). The three EIL classifications show the multicultural and multilingual contexts of ELT. Consequently, a certain instructional approach that works in the inner circle sometimes should be adapted before it is applied in the outer and expanding circles.

Not only does the sociolinguistic landscape of English change, but also the reasons why a student learns English. Brown (2012) notes the global reasons and local reasons why people learn English. Global reasons include the study of English as a means of communicating globally, to foster globalism, to achieve higher education, and to access global information. Local reasons refer to such reasons as working locally with foreigners, acquiring prestige, or meeting certain English requirements in school or work. While it is true that many learners want to learn native-like English, English educators should not ignore the local reasons for learning English. Flowerdew (2012) affirms that some learners might want to preserve their cultural identity as non-native speakers. They do not force themselves to sound like native speakers due to the argument that the 'real' English is not just the one used in inner circle countries. It is obvious that English is nowadays learned for diverse uses by various users.

From EIL perspective, English is no longer seen as a static and monolithic entity in that it changes and adapts when it is transplanted to a new sociolinguistic and sociocultural context. Matsuda (2012) notes such phenomena as nativization that might occur in phonology, morphology, lexicons, syntax, semantics, pragmatics, and discourse layers. Bokhorst-Heng (2012) notes that in the lexical level, for instance, the so-termed Pakistani English possesses particular collocation of 'commit zina (adultery)' and 'recite kalam (verse)' as a result of the combination between English and Urdu lexicons. In the discourse level, Al-Faruqi (1987) introduces the notion of Islamic English as a response to the incorrect translation and introduce the concept of Islamic English language curriculum as to bridge western educational philosophy and Islamic perspectives. Brown (2012) introduces the concept of 'locally defined EIL' in that the elements of the curriculum such as units of analysis, objectives, contents, teaching strategies, models, and resources should be carefully developed on the basis of the local needs. The accommodation of students' local needs should not be seen as an effort of diminishing international uses of English.

A radical response to the linguistic and cultural diversity of ELT is introduced by Kumaravadivelu (2012b) through the notion of an epistemic break, that is breaking the dependency on the western terminology and knowledge production, center-based methods, center-based cultural competence, and center-based textbook industry. The English teachers are supposed to design a contextually-relevant and culturally-sensitive teaching materials that fit their students' contexts.

In response to the discussion of EIL, an English teacher in an expanding circle country might need to develop teaching materials or an instructional model that accentuates his 
or her sociolinguistic and sociocultural contexts. In a case of developing an instructional model for an Islam-affiliated university within Indonesian context, an English teacher should appropriately include the international goals of English learning, accommodate Indonesian cultural elements, and incorporate Islamic values and tradition.

\section{METHOD}

This article was a dissertation chapter conducted within the so-termed research and development design which consisted of four main stages namely: studying relevant literature and research findings, developing an educational product based on the study, field testing the product, and revising the product (Borg \& Gall, 1983). The type of this study was a research and development, which in this article was closely connected to a qualitative method, with the aims of developing and validating an educational product.

The participants of this research were two experts who involved in the studying relevant literature and research findings; three other experts and five practitioners in the initial development of the model; thirty-three students in the field testing of the developed model; and six experts in the revising stage of the model. Interviews, observations, and questionnaires, which had been validated through experts' judgment, were used to collect the data during development process of the educational product.

The materials of this research study included two songs, four poems, and fourteen short stories taken from Western, Indonesian, and Islamic traditions are used as the learning materials. The materials were prepared through a needs analysis instrument and experts' judgment from the fields of English reading instruction, literature teaching, and instruction evaluation. The research instrument was created by researchers and was validated both qualitatively, through expert judgements, and quantitatively with Cronbach's Alpha value of .805 .

The procedure of the research was as follows: first, initial instructional model, which consisted of a framework and supporting learning materials, was designed under the supervision of two experts in literature teaching; second, the first draft of the model was assessed by three experts and five practitioners in the field of English reading instruction and English literature teaching. The feedback from the experts and practitioners were used as the basis to revise the second draft of the model; third, thirteen units of learning materials which were designed in tune with the model were tried out for 33 sophomore students of English language department at State Islamic Institute of Metro, Indonesia. The student voice, which according to Shim and Shur (2017) is commonly taken as insignificant aspect, is considered in the improvement of the developed model; fourth, the report of the try out was critically read and examined by six experts in the field of English reading instruction, literature teaching, instruction evaluation, and Islamic education. The feedback from the experts was used to devise the final framework of the model. The main data collection stage took place during 6 months that was from February to August of 2017.

\section{FINDINGS}

The literature-based reading instruction (LBRI) Model is underpinned by three assumptions. First, meaningful English learning involves the particularities of students' 
milieu. The existing model, Stern's teaching-learning model as presented in Figure 1., is designed for ELT in general. It does not cover a reading instruction using literature in a specific milieu like an Islamic university in Indonesia.

Second, an English reading instruction at an Islamic university is holistic when it involves literature and Islamic tradition. Brown (2007) notes the phenomenon of the butterfly effect as to describe the complexity of variables in theory of second language acquisition in that a factor which is apparently insignificant might turn out to be a crucial factor. Thus, the developed model of this research study assumes that literature and Islamic educational philosophy and tradition are the pathways that both teachers and learners, in an Islamic university, could take in order to develop English reading achievement.

Third, a literature-based reading instructional model is effective when it is facilitated by a clear instructional design. Smith and Ragan (2005) urge that the term instructional design deals with a teacher's systematic and reflective effort in transforming the teaching and learning principles into the learning materials, learning activities, and evaluation system. On the other hand, Carr-Chellman (2011) holds that the term instructional design refers to a systematic process consisting of nine basic steps: writing instructional goals; creating learning objectives; writing matching assessment/test items; analyzing student characteristics; selecting materials/text; designing activities; selecting or developing suitable media/technology; implementing the plan; and evaluating and revising the instruction.

The above three assumptions were used as the springboard in developing the framework of the LBRI Model as depicted in Figure 2.

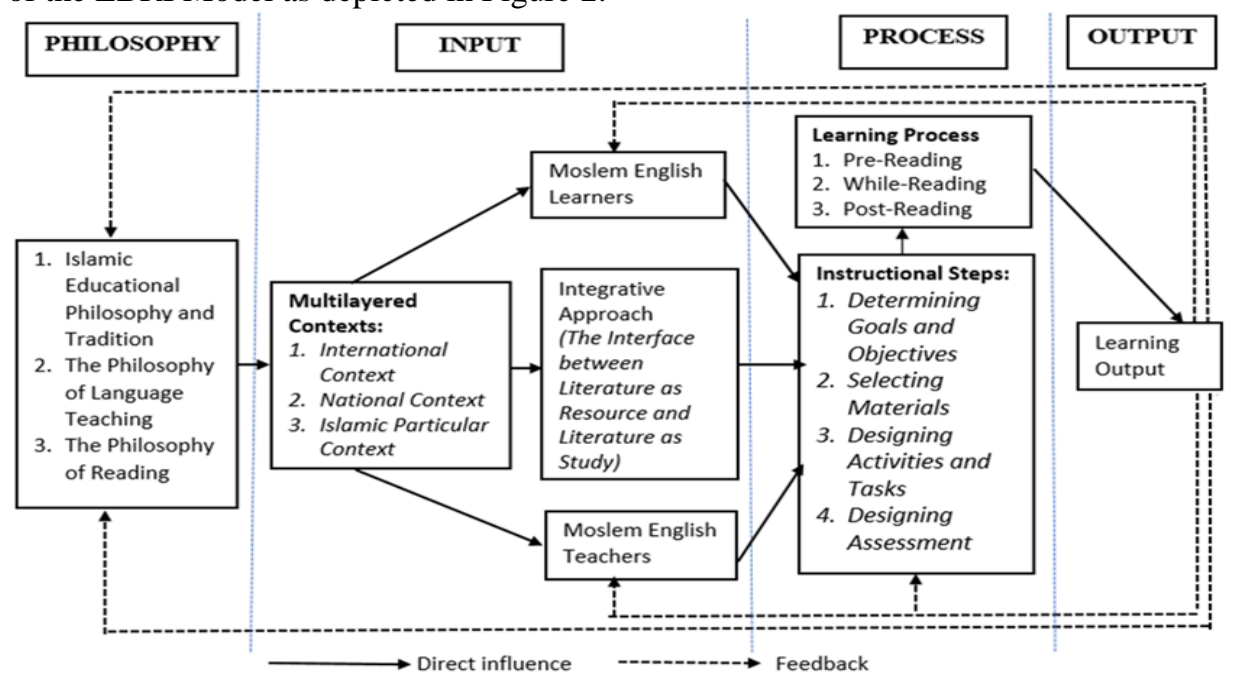

Figure 2

A Literature-Based Reading Instructional Model for Islam-Affiliated University in Indonesia 
Figure 2. showed that the Islamic educational philosophy and tradition, the philosophy of language teaching, and the philosophy of reading, served as the spirit that holds together the entire components of the LBRI Model. They directly influence the instructional inputs (multi-layered contexts of a learning environment, learner, approach, and teacher) and the process (teaching and learning activities). The subcomponents of the input and process interacted to achieve learning output of teaching reading with literature at an Islamic university. The learning output also served as the feedback for the improvement of the input and the process of the LBRI Model.

\section{The Components of the LBRI Model}

The LBRI Model consists of four main components: philosophy, input, process, and output. The elaboration of each component is presented below.

\section{Philosophy}

Islamic Educational Philosophy and Tradition. One of the sayings that best reflects the Islamic educational philosophy is 'knowledge is light and the light of Allah is not bestowed upon a sinner' (al 'ilmu nüurun wa nürullāh lā yuhdā lil 'āshiy). True knowledge is a light (ontology) which is sacred and gained through spiritual exercises (epistemology), and should be utilized to realize the existence of Allah (axiology). The pursuit of knowledge is seen as an intellectual as well as a spiritual journey. Intellectual capacity is needed to attain a true understanding of Islam as the Prophet Muhammad s.a.w. said: "Religion is a reason and there is no religion for those who have no reason." Reasoning capability alone is not enough in that it should be developed in the light of transcendental orientation, as the Prophet also said: "Any matter of importance which is not begun with bismillah remains defective." Without spiritual aspect, an intellectual development process is incomplete.

As the intellectual and spiritual domains should blend together in harmony, the transcendental sources of knowledge (Qur'an and Sunnah) and human's reasoning capability ('aql) should be utilized in harmony. The ultimate goal of utilizing 'aql is to digest the existence of Allah Himself. Nasution (2013) maintains that all knowledge comes from Allah and should be used to help humans get closer to Allah. This belief helps explain the common prayer offered by a Moslem student before learning: "In the Name of Allah the Most Beneficent, the Most Merciful. I am pleased with Allah as my Lord, with Islam as my religion, and with Muhammad s.a.w. as the prophet and messenger of Allah. O Allah, advance me in knowledge and true understanding." Prior to true understanding is the acknowledgment of Allah as the ultimate source of knowledge.

Halstead (2004) emphasizes that the pursuit of knowledge would only be a worship when it is conducted under the guiding spirit of the Quranic revelation and the Prophetic precedent. Alwasilah (2010), on the other hand, specifically points out that the Quranic verses like Al-Hujurat 49: 13 and Ar-Rum 30: 22, serve as the basis of the language pedagogy. Like all other branches of knowledge, the study of language pedagogy should be underpinned by the revelation so that it would lead the learners to the realization of Allah. 
Religious control is central to Islamic educational tradition. Shah, et al., (2012) argue that an English language curriculum for Islamic institutional context should be underpinned by the tauhīd paradigm. It is suggested that an English educator be skillful in English and be well-versed in Islamic teaching so that he or she will be able to disseminate Islamic beliefs and Islamic code of conduct when teaching English.

A Moslem teacher should comply with certain code of conduct such as possessing endless forbearance, having a continual humility, being not arrogant except to those oppressing his/her students, being humble in classrooms and academic meetings, being not talkative, not talking nor joking meaninglessly, having innumerable kindness towards his/her students, not making a hasty decision, correcting his/her students' mistakes without humiliating them, being open and objective, being attentive to the questions asked by his/her students; accepting the truth in others' argument, perpetuating the truth, reminding his/her students that Allah's pleasure is the ultimate goal of learning, guiding his/her student to accomplishing their individual obligation prior to their collective obligation, and becoming a good role model spiritually and academically. Meanwhile, a Moslem student should understand and implement such code of conduct as: greeting the teacher first, being not talkative in negative sense, asking teacher's permission before asking question or delivering argument, not making an impression in that $\mathrm{s} / \mathrm{he}$ is more knowledgable than his/her teachers, talking politely to the teachers in the right time and moment according to them, having no negative thinking toward the teachers' actions, and understanding the morals within the story of the Prophet Moses and the Prophet al-Khadir (Quasem, 1979). It is worth noting that literature, particularly the story of Moses and al-Khadir, underpins the code of conduct of Islamic education.

It is worth noting that the above code of conduct might be universal except that of a Muslim teacher should always remind the students about the spiritual orientation of the knowledge pursuit. It is that transcendental aspect that makes Islamic educational tradition distinctive from that of the western. Diallo (2012) notes the difference between Islamic education tradition and western education tradition. The former views the pursuit of knowledge as sacred while the latter sees it as a process that should be free from religious control. Shihab (2013) emphasizes that for a Moslem scientist, the acquired knowledge should lead to the recognition of and admiration for Allah, as well as to a sincere and obedient worshipper. "From among His servants, it is only those who know (scientists) that fear Allah.” (QS. Fâthir 35: 28).

Islamic educational philosophy and tradition itself have undergone some changes which lead into different appreciation toward the advance of science and technology. Muhajir (2013: 72) notes, for example, that some educationists might adopt the classification of knowledge into ilmu fardhu 'ain, which is binding on every Moslem, and ilmu fardhu kifayah, which is not obligated on every Moslem. The adoption of such classification makes them fail at appreciating the development of science and technology. Meanwhile other educationists might adopt the notion stating that religious sciences (ulumul al-din) and secular sciences (ulumu al-dunya) should not be put in a clear-cut division for all branches of knowledge are from Allah. The proponents of the last notion mentioned might appropriately appreciate the development of science and technology as well as the notion of interconnection and integration of knowledge. 
Further, Tan (2014) confirms that many Moslem educators in Indonesia reject the notion that modern subjects are identical to western subjects, and thus they view all branches of knowledge are from God. They tend to believe that the so-termed religious sciences and modern sciences are integrated in the Islamic educational philosophy and tradition. It is noteworthy, then, to state that education practitioners in Indonesia ought to be open to Western subjects, like English language teaching, without being afraid of being westernised.

The Philosophy of Language Teaching. Language teaching philosophy deals with the suitable approaches and methods that help foreign language learners to gain intended results (Bobykina, 2015). The approach underpinned the LBRI Model is the so-termed integrative approach, while the method is Contextual Teaching and Learning (CTL). The LBRI Model adopts an integrative approach which is built around the notion that: (a) the existing methodological approaches should not be used independently to teach literature in the EFL classrooms; and (b) an appropriate approach should include personal, cultural, and linguistic ingredients (Bobkina \& Dominguez, 2014). In implementing the integrative approach, a teacher should make use of what works best to enhance students' personal growth, cultural understanding, and linguistic competency. CTL best suits the LBRI Model for it has been successfully used to respond the students' low reading ability by utilizing literary texts and connecting them with the students' contexts (Johnson, 2002). CTL is aimed at helping students see meaning by connecting the materials with their personal, social, and cultural context. Within the LBRI Model, the principles and components of CTL are reflected through such activities as: comparing target culture with students' culture, demonstrating text, writing a review/or synopsis, working in small groups, discussing symbolic meaning, imagining of being a character, achieving five levels of reading comprehension, and implementing authentic assessment.

The Philosophy of Reading. Reading is a process of making meaning from a text which requires vocabulary knowledge, grammatical knowledge, and prior knowledge. People might read for daily activities; for learning new things; for life purpose; for pleasure and leisure like reading a novel or religious text; for academic purposes; and for work purposes (Richards, 2015). It is worth noting that the way a person reads is highly dependent upon his or her purpose of reading. From Islamic perspectives, stating the purpose, intention or niyyah, of reading is prominent: "Actions are but by intention and every man shall have but that which he intended" (Related by Bukhari and Muslim). Thus, the purpose should be to obey Allah's command and to enrich cultural understanding: "Read in the Name of your Lord who created" (QS. Al-'Alaq 96: 1); "And of His signs is the creation of the heavens and the earth and the diversity of your languages and your colors. Indeed, in that are signs for those of knowledge" (QS. ArRum 30: 22); and "O mankind! Indeed, we created you from a male and a female, and made you nations and tribes that you may identify yourselves with one another." (QS. Al-Hujurāt 49: 13). English Moslem teachers should remind English Moslem learners that reading skills enhancement needs proper niyyah, adequate vocabulary and grammar knowledge, and appropriate prior knowledge. The teachers should emphasize that the knowledge or insight gained from the reading activities is a gift from Allah: "Exalted are 
You: we have no knowledge except what You have taught us. Indeed, it is You who is the Knowing, the Wise" (QS. Al-Baqarah 2: 32). As such, an EFL reading class would be in tune with the Islamic educational philosophy and tradition.

Input

International Context. Current global issues within second language education were being considered in the development of the LBRI Model. Among the issues were the importance of preserving the individual identity and building a locally defined model of English teaching. Kumaravadivelu (2012b) asserts that English teachers in an expanding circle country should try to produce learning materials that address the issues of individual identity. Brown (2012) also advocates the concept of locally defined EIL, English as an international language, to accommodate local needs of students in countries where English is not the native language. The LBRI Model was developed in the spirit of maintaining the individual identity of Moslem students and of integrating particular needs of Islamic university into second language teaching area.

National Context. TEFL field in Indonesian national context is now facing the challenges of implementing character education and of interpreting the post method pedagogy. The former implies the important role of religion in shaping the desired characters in that Muslim learners, for example, might refer to the Prophet Muhammad and the concept of akhlaqul karimah (Sugirin, 2011). The latter pertains to the notion of particularity which requires a multi-layered situational analysis on institutional context, national context, and global context (Madya, 2013). The LBRI Model is developed for Muslim learners without excluding the national and global contexts of the instruction English reading instruction in Indonesia.

Islamic Particular Context. Indonesian educational policy recognizes the demarcation between general higher education and Islamic higher education. The LBRI Model was developed for Islamic higher education or Islamic university. The students of the English department at Islamic university were required to be good at language skills and be knowledgeable about Islamic beliefs and values.

Moslem English Learners. The LBRI Model fitted the learners with the following characteristics: (1) Islam in term of religion; (2) second year students of the English Department at Islamic university; (3) willing to read literary texts from inner circle countries, Indonesian national background, and Islamic world or tradition; and (4) willing to learn reading skills and values.

Integrative Approach. Literature is a distinctive mode of communication as it is commonly written with the intention to entertain, educate, and encourage its readers to be better persons. It needs, however, particular ways of reading: efferent reading and aesthetic reading. The former focuses on the information within a given text, and the latter focuses on what readers are thinking, feeling, and experiencing (Cox, 2012). As such, a single approach to teaching literature is not enough to accommodate the nature of literature and the nature of reading literature. Bobkina (2014) urges that an integrative approach-- which emphasizes linguistic, cultural, and personal domains-is a sound alternative to teaching literature in the EFL classroom. 
Moslem English Teachers. The LBRI Model was effective when a teacher met the following characteristics: (1) Islam in term of religion; (2) having professional training in English language teaching with a master degree at minimum; (3) willing to utilize literary texts from inner circle countries, Indonesian national background, and Islamic world; (4) willing to integrate aqidah/tauhid, muamalah, and akhlaqul karimah values into reading instruction; (5) willing to utilize literary texts to teach reading skills and values.

\section{Process}

Learning Process. It refers to the activities and tasks of the LBRI Model which weregrouped into three common stages of a reading instruction namely pre-reading, while-reading, and post-reading stages. Table 1. summarizes the learning process of the developed model.

Table 1

The Activities and Tasks of the Pre-reading, While-reading, and Post-reading Stages

\begin{tabular}{|c|c|c|c|}
\hline No. & Stages & Activities & Tasks \\
\hline \multirow[t]{4}{*}{1.} & \multirow{4}{*}{$\begin{array}{l}\text { Pre- } \\
\text { reading }\end{array}$} & \multirow{2}{*}{$\begin{array}{l}\text { a. Cultural background } \\
\text { exploration }\end{array}$} & 1) Exposing the cultural background of the text \\
\hline & & & $\begin{array}{l}\text { 2) Comparing target cultural background with the students' } \\
\text { own }\end{array}$ \\
\hline & & b. Prediction & $\begin{array}{l}\text { 3) Making a general prediction based on a title, visual aids, } \\
\text { sentences, or paragraphs }\end{array}$ \\
\hline & & c. Vocabulary building & 4) Discussing the vocabularies which are central to the text \\
\hline \multirow[t]{10}{*}{2.} & \multirow{10}{*}{$\begin{array}{l}\text { While- } \\
\text { reading }\end{array}$} & \multirow[t]{4}{*}{ d. Understanding the plot } & 5) Answering questions that cover the key details of the story \\
\hline & & & 6) Putting events in order \\
\hline & & & 7) Paraphrasing the story \\
\hline & & & 8) Dividing the story into several parts \\
\hline & & \multirow{3}{*}{$\begin{array}{l}\text { e. Understanding the } \\
\text { characters }\end{array}$} & 9) Identifying adjectives that describe the characters \\
\hline & & & 10) Inferring character trait \\
\hline & & & 11) Ranking the characters \\
\hline & & \multirow[t]{2}{*}{ f. Vocabulary study } & $\begin{array}{l}\text { 12) Answering multiple-choice questions on difficult } \\
\text { vocabulary }\end{array}$ \\
\hline & & & 13) Organizing words \\
\hline & & g. Language study & 14) Inferring certain linguistic aspects \\
\hline \multirow[t]{7}{*}{3.} & \multirow{7}{*}{$\begin{array}{l}\text { Post- } \\
\text { reading }\end{array}$} & \multirow{2}{*}{$\begin{array}{l}\text { h. Interpreting the main } \\
\text { themes }\end{array}$} & 15) Discussing possible themes \\
\hline & & & 16) Discussing symbolic meaning \\
\hline & & \multirow{2}{*}{$\begin{array}{l}\text { i. Understanding } \\
\text { narrative point of view }\end{array}$} & 17) Imagining of being a character in the story \\
\hline & & & 18) Changing the point of view of the story \\
\hline & & j. Writing activity & 19) Writing a review or synopsis of the story \\
\hline & & \multirow[t]{2}{*}{ k. Sharing activity } & 20) Demonstrating the given text \\
\hline & & & 21) Discussing the values depicted in the text \\
\hline
\end{tabular}

Instructional Steps. Instructional steps refer to what a teacher needs to do to bring about learning. The steps proposed in the LBRI Model included: (1) determining goals and objectives, (2) selecting materials, (3) designing tasks and activities, and (4) designing assessment.

Output

The output of the learning is gained through the assessment activities. With regard to this, the LBRI Model alternately applies traditional assessment and authentic 
assessment. The former was used to assess the efferent reading tasks which emphasize the linguistic elements, and the latter was for the aesthetic reading tasks that focus on psychological and aesthetical responses toward a text. Both types of assessment are based on Barrett's taxonomy level: literal comprehension, reorganization, inferential comprehension, evaluation, and appreciation (Göçer, 2014).

\section{DISCUSSION}

This study aimed to develop and validate a literature-based reading instructional model for students of English department at the Islam-affiliated university in Indonesia. The model was designed to maximize the multidimensional theoretical advantages of literature, ranging from reading skill enhancement to values inculcation, for beginner readers by taking into account the multi-layered existing educational contexts: international, national, and Islamic contexts. By instructional model, the researchers referred to a visualized framework pertinent to how such instructional components as philosophy, contexts, teaching approach, learners' characteristics, and teachers' characteristics work together and are practically interconnected one another. As such, the LBRI model development is in line with Zeng's concern (2017) of interconnecting theory and practice, or theorizers and practitioners.

In this study, the LBRI model might be reasonably connected with Tan's findings (2014) stating that most Islamic educational institutions in Indonesia have no problem with learning both religious subjects and the so-termed modern secular subjects as it is believed that all knowledge is from God. The institutions are also willing to incorporate both traditional didactic teaching methods, which are still widely used in most Islamic schools, and student-centered pedagogies brought by western educational system.

The LBRI Model is also in tune with the spirits previously proposed by some scholars. Alkire and Alkire (2007) urge that the use of bicultural literary works -Western writers exploring the Muslim world and Muslim writers exploring the West-- minimizes conflicts that might arise between Muslims and Western literature. Alahdadi and Ghnizadeh (2017) argue that exposing students to various conditions and different cultural information in TEFL can enhance students' cultural intelligence (CQ). Misco (2018) finds that reading enrichment is a promising strategy in strengthening a culturally responsive pedagogy. The use of extensive reading approach is promising in enhancing students' proficiency in Indonesian higher education context (Renandya, et.al., 2018). The LBRI Model views that literary text is a powerful instrument to enhance students' cultural understanding and English proficiency.

It is noteworthy that the inclusion of Indonesian literary texts in addition to the Islamic literary texts and western literary texts in the LBRI Model supports the belief, proposed by Nurgiyantoro and Efendi (2017), that readers could not detach themselves from the cultural background and values that have raised them. As such, the LBRI Model shed light on the incorporation of the students' multilayered cultural contexts in TEFL.

An important implication of this research is that it allows TEFL practitioners redesign their instructional model by accommodating religious texts, local texts, or indigenous texts to fit the locality and particularity of their teaching contexts. 


\section{CONCLUSION}

As the most populous Muslim country in the world, Indonesia possesses a large number of Muslim English learners whose national cultural background and religion affiliation should be incorporated into a literature-based instructional model. In focusing on the international aspects of English language teaching, English teachers at Islam-affiliated universities should not lose their sight of the national and the Islamic aspects. They should accommodate the learners' national and ideological contexts, in addition to the international context embedded in the TEFL, to reduce the stigma whereby English learning is a threat to Indonesian culture and Islamic tradition. The blending of literary texts from Western, Indonesian, and Islam tradition is then unavoidable to help students enhance their cross-cultural reading ability and to make them aware that reading literature is a promising springboard to identify themselves with different nations and tribes.

\section{Acknowledgments}

The writers would like to thank Prof. Suwarsih Madya, Ph.D., Prof. Dr. Margana, M.Hum., Joko Priyana, Ph.D., Dr. Agus Widyantoro, and Prof. Noorhaidi, Ph.D. for reading and examining this study critically.

\section{REFERENCES}

Alahdadi, S., \& Ghanizadeh, A. (2017). The dynamic interplay among EFL learners' ambiguity tolerance, adaptability, cultural intelligence, learning approach, and language achievement. Iranian Journal of Language Teaching Research, 5(1), 37-50.

Al-Faruqi, I. R. (1986). Toward Islamic English. Virginia: International Institute of Islamic Thought.

Alkire, S., \& Alkire, A. (2007). Teaching literature in the muslim world: A bicultural approach. Teaching English as a Second of Foreign Language, 10(4), 1-13.

Alkouatli, C. (2018). Pedagogies in becoming Muslim: Contemporary insights from Islamic traditions on teaching, learning, and developing. Religions, 9(11), 367-384. https://doi.org/10.3390/re19110367

Alwasilah, A. C. (2010). Filsafat bahasa dan pendidikan. Bandung, Indonesia: PT Remaja Rosdakarya.

Alwasilah, A. C. (2014). Islam, culture, and education: Essays on contemporary Indonesia. Bandung, Indonesia: PT Remaja Rosdakarya.

Bayat, M., \& Jamnia, M. A. (1994). Tales from the land of the sufis. Boston: Shambala.

Bobkina, J., \& Dominguez, E. (2014). The use of literature and literary texts in the EFL classroom: Between consensus and controversy. International Journal of Applied Linguistics \& English Literature, 3(2), 248-260.

Bobykina, I. (2015). My philosophy of teaching foreign languages. Procedia-Social and Behavioral Sciences, 186(2015), 684-687.

Bokhorst-Heng, W. D. (2012). Lexical innovation in English as an international language: Implications for English teaching. In L. Alsagoff, et.al. (Eds.), Principles and practices for teaching English as an international language (pp. 206-225). New York: 
Routledge.

Borg, W. R., \& Gall, M. D. (1983). Educational research: an introduction (4th ed.). New York: Longman.

Brown, H. D. (2007). Principles of language learning and teaching (5th ed.). New York: Pearson Education, Inc.

Brown, J. D. (2012). EIL curriculum development. In L. Alsagoff, et.al. (Eds.), Principles and practices for teaching English as an international language (pp. 147167). New York: Routledge.

Budsaba, K., \& Todsapon, S. (2018). Celebrating local, going global: Use of Northern Thainess-Based English lessons. The Journal of AsiaTEFL, 15(2), 292-309. https://doi.org/10.18823/asiatefl.2018.15.2.3.292

Carr-Chellman, A. A. (2011). Instructional design for teachers. New York: Routledge.

Carter, R., \& Long, M. N. (1991). Teaching literature. New York: Longman Publishing.

Collie, J., \& Slater, S. (1994). Literature in the language classroom: A resource book of ideas and activities. Cambridge: Cambridge University Press.

Cox, C. (2012). Literature-based teaching in the content areas. California: SAGE Publications, Inc.

Dewi, N. (2016). Words'wonder: Beginners' guide to literature. Yogyakarta, Indonesia: Sanata Dharma University Press.

Diallo, I. (2012). The interface between Islamic and Western pedagogies and epistemologies and epistemologies: Features and divergences. International Journal of Pedagogies and Learning, 7(3), 175-179.

Göçer, A. (2014). The assessment of Turkish written examination questions based on the text in accordance with the Barrett's taxonomy. IJLET, 3, 1-16.

Hadi, W. M. A. (2016). Kembali ke akar kembali ke sumber. Yogyakarta, Indonesia: DIVA Press.

Halstead, J. M. (2004). An Islamic concept of education. Comparative Education, 40(4), 517-528.

Hasan, Noorhaidi. (2018). Literatur keislamana generasi milenial: transmisi, apropriasi, dan kontestasi. In N. Hasan (Eds.), Literatur Keislaman Generasi Milenial: Transmisi, Apropriasi, dan Kontestasi (p. 1-27). Yogyakarta: Pascasarjana UIN Sunan Kalijaga Press.

Johnson, E. B. (2002). Contextual teaching and learning: What it is and why it's here to stay. California: Corwin Press, Inc.

Joyce, B., Weil, M., \& Calhoun, E. (2009). Models of teaching (8th ed.). Boston: Pearson Education, Inc.

Kafi, Z., Motallebzadeh, K., \& Ashraf, H. (2018). University instructors' teaching experience and their perception of professional ethics: Postulating a model. International Journal of Instruction, 11(4), 257-270. https://doi.org/10.12973/iji.2018.11417a 
Khairuddin, Z., Shukry, A. S. M., \& Sani, N. A. (2014). Reading trends and perceptions towards Islamic English websites as teaching materials. English Language Teaching, 7(8), 124-133.

Kumaravadivelu, B. (2012a). Language teacher education for a global society. New York: Routledge.

Kumaravadivelu, B. (2012b). Individual identity, cultural globalization, and teaching English as an international language: the case for an epistemic break In L. Alsagoff, et.al. (Eds.), Principles and practices for teaching English as an international language (pp. 9-27). New York: Routledge.

Lazar, G. (2009). Literature and language teaching. Cambridge: Cambridge University Press.

Madya, S. (2013). Metodologi pengajaran bahasa: dari era prametode sampai era pascametode. Yogyakarta, Indonesia: UNY Press.

Madya, S. (2015, February). Maximizing students' learning of English communicative competence through the use of literature. A Paper presented at TEFLIN's regional seminar in Palembang. Retrieved July 27, 2017 from http://staff.uny.ac.id/sites/default/files/pendidikan/prof-hj-suwarsih-madyaphd/maximizing-students-learning-cc-thr-use-literature-palembang-7-febr-2015-1.pdf

Maley, A. (2012). Literature and language teaching. In L. Alsagoff, et.al. (Eds.), Principles and practices for teaching English as an international language (pp. 299317). New York: Routledge.

Matsuda, A. (2012). Principles and practices of teaching English as an international language. Canada: Multilingual Matters.

Misco, T. (2018). Culturally responsive curriculum and pedagogy in the commonwealth of the northern mariana islands. International Journal of Multicultural Education, 20(2), 81-100.

Mohammad, Khatib, Hossein, A., \& Rahimi. (2012). Literature and language teaching. Journal of Academic and Applied Studies, 2(6), 32-38.

Motallebzadeh, K., Ahmadi, F., \& Hosseinnia, M. (2018). Relationship between 21st century skills, speaking and writing skills: A structural equation modelling approach. International Journal of Instruction, 11(3), 265-276. https://doi.org/10.12973/iji.2018.11319a

Muhajir. (2013). Filsafat pendidikan Islam syi'ah. Yogyakarta: Pustaka Pelajar.

Muslim, A.B. (2017). Heritage narratives, motivation to learn English and the development of national identity: an Indonesian perspective. The Journal of Asia TEFL, 14(3), 414-429.

Nasution, H. (2013). Teologi Islam: Aliran-aliran sejarah analisa perbandingan. Jakarta, Indonesia: Penerbit Universitas Indonesia.

Nurgiyantoro, B., \& Efendi, A. (2017). Re-actualisation of puppet characters in modern Indonesian fictions of the 21st century. 3L: The Southeast Asian Journal of English Language Studies, 23(2), 141-153. 
Purwati, N., Zubaidah, S., Corebima, A. D., \& Mahanal, S. (2018). Increasing Islamic junior high school students learning outcomes through integration of science learning and Islamic values. International Journal of Instruction, 11(4), 841-854. https://doi.org/10.12973/iji.2018.11453a

Quasem, M. A. (1979). Al-Ghazãlî on islamic guidance. Selangor: National University of Malaysia.

Renandya, W. A., Hamied, F. A., \& Joko, N. (2018). English language proficiency in Indonesia: Issues and prospects. The Journal of AsiaTEFL, 15(3), 618-629. https://doi.org/10.18823/asiatefl.2018.15.3.4.618

Richards, J. C. (2015). Key issues in language teaching. Cambridge: Cambridge University Press.

Rosenblatt, L. M. (2005). From literature as exploration and the reader, the text, the poem. Voices From the Middle, 12(3), 25-30.

Shah, M. I. A., Muhammad, A. J., \& Ismail, S. M. (2012). Design, formulation, and implementation of an English language curriculum from islamic perspective. Journal of Islam in Asia, 9, 180-198.

Shihab, M. Q. (2013). Kematian adalah nikmat. Tangerang, Indonesia: Penerbit Lentera Hati.

Shim, J. M., \& Shur, A. M. (2017). Learning from ELLs' perspectives: Mismatch between ELL and teacher perspectives on ELL learning experiences. English Language Teaching, 11(1), 21-32. https://doi.org/10.5539/elt.v11n1p21

Smith, P. L., \& Ragan, T. J. (2005). Instructional design (3rd ed.). New Jersey: John Wiley \& Sons, Inc.

Stern, H. H. (1991). Fundamental concepts of language teaching. Oxford: Oxford University Press.

Sugirin. (2011). Character education for the EFL student-teachers. Cakrawala Pendidikan, Edisi Khusus Dies Natalis UNY, 1-14.

Tan, C. (2014). Educative tradition and Islamic schools in Indonesia. Journal of Arabic and Islamic Studies, 14(2014), 47-62.

The Holy Qur'an

Vacca, J. A. L, Vacca, R. T., \& Gove, M. K., McKeon, C. A., Burkey, L. C., \& Lenhart, L. A. (2006). Reading and learning to read. Boston: Allyn \& Bacon.

Zeng, Z. (2017). Construction of EFL student teachers' beliefs about method: Insights from post method. English Language Teaching, 11(1), 93-99. https://doi.org/10.5539/elt.v11n1p93 